\title{
Development and Content Validation of the Adaptation Process in Academia Questionnaire for Occupational Therapy Educators
}

\author{
Maria Concepcion C. Cabatan, ${ }^{1}$ Lenin C. Grajo ${ }^{2}$ and Erlyn A. Sana ${ }^{3}$ \\ ${ }^{1}$ Department of Occupational Therapy, College of Allied Medical Professions, University of the Philippines Manila \\ ${ }^{2}$ Programs in Occupational Therapy, Department of Rehabilitation and Regenerative Medicine, Vagelos College of Physicians and Surgeons, Columbia University \\ ${ }^{3}$ National Teacher Training Center for the Health Professions, University of the Philippines Manila
}

\begin{abstract}
Objective. The process of adaptation in academia can best be understood and measured using valid and reliable tools. To understand how occupational therapy educators adapt to academic roles and how they use adaptation to build academic careers, the Adaptation Process in Academia Questionnaire (APA-Q) was developed. The APA-Q is a 199-item tool with four sections: academic experiences (104 items); contexts (16 items); adapting responses (13 items); and adaptation outcomes (66 items). This study described the development and the process of determining the content validity of the APA-Q.
\end{abstract}

Method. We conducted an extensive review of literature and the available faculty instruments in developing the APA-Q items. Six content experts were recruited to rate the 199-item and scale relevance of the instrument. Qualitative feedback were provided from open-ended questions. Item and scale content validity indices (I-CVI/S-CVI) were calculated. CVI and qualitative assessment informed questionnaire revisions.

Results. Content experts rated 161 of the items (81\%) to be highly relevant. The I-CVI of 30 items was acceptable (0.83). Eight items were rated irrelevant (0.5-0.66).

S-CVI was excellent (0.97). In terms of constructs, experts agreed on the relevance of items (>0.80): academic experiences (99 or $95 \%$ ); contexts (16 or 100\%); adapting responses (12 or $92 \%)$; and adaptation outcomes (63 or $95 \%)$.

Qualitative assessment indicated a lack of clarity in some items and instructions, redundancy in some of the items, the use of jargon, and missing items. Based on I-CVI and qualitative assessment, 12 items were deleted, 13 items were revised, and 10 items were added.

Conclusion. Context experts deemed the APA-Q to be relevant. Further establishment of its construct validity and reliability is warranted.

Key Words: adaptation, content validity, tool development, occupational therapy

Oral presentation, University of the Philippines Manila 2019 Graduate Students Colloquium, April 12, 2019, Cherry Blossoms Hotel, Ermita, Manila.

Poster presentation, 53 $3^{\text {rd }}$ Japan Occupational Therapy Congress \& Expo, September 6-8, 2019, Fukuoka, Japan.

Corresponding author: Maria Concepcion C. Cabatan, MHPEd, OTRP, OTR, FPAOT

College of Allied Medical Professions

University of the Philippines Manila

Academic Compound, Pedro Gil St.,

Ermita, Manila 1000, Philippines

Email: mdcabatan@up.edu.ph

\section{INTRODUCTION}

\section{Adaptation in the Academic Setting}

Adaptation is important in a person's lifespan in mastering a chosen occupation. In occupational therapy, occupation is defined as a meaningful and purposeful activity which individuals engage in for health and wellbeing. ${ }^{1}$ Scholars have defined adaptation as a process and an outcome. ${ }^{2,3}$ As a process, it is internal to a person that enables participation in an occupation and role fulfillment such as that of an educator or faculty. As an outcome, 
adaptation is observed when a person is able to effectively and efficiently participate in occupational roles leading to an outcome such as career success, productivity, quality of life, and satisfaction., ${ }^{2,4}$ The adaptation process is manifested as the individual fulfills his work-role expectations and experiences challenges in the fulfillment of these roles. ${ }^{4}$

Two theories are used to explain how individuals respond to challenges and use adaptation to build careers: The Theory of Occupational Adaptation ${ }^{5}$ and Career Construction Theory. ${ }^{4}$ The Theory of Occupational Adaptation states that adaptation is a process that individuals utilize to master the environment through a chosen meaningful activity (or occupation) and respond to challenging experiences that arise from transactions in his environment. ${ }^{5,6}$ Career Construction Theory states that people adapt to work experiences, expectations, and use adaptation to build careers and deal with occupational transitions. ${ }^{7}$ Both theories view individuals as having the capacity to self-regulate to respond to challenging experiences. Occupational Adaptation scholars refer to this self-regulation as adaptive capacity whereas Career Construction Theory refers to it as adaptive readiness, adaptability to resources, and adapting responses.

Faculty are an important resource in shaping student learning in institutions of higher education. ${ }^{8}$ In view of changing higher education landscape, the faculty will need to be more adaptive to work demands and expectations. ${ }^{8}$ Recruitment, retention, and increasing the number of competent faculty is important in the health profession education. ${ }^{9}$ More so in the occupational therapy profession in the Philippines where less than five percent of practitioners are in the academe. In the health sciences, the workload of faculty includes basic sciences, clinical teaching or both. ${ }^{10}$ Sana ${ }^{10}$ asserts that there are differences in terms of responsibilities and credit loads in basic sciences and clinical teaching.

Allied health academics in their initial years in academia need to adjust to novel occupational demands primarily because there may be no explicit preparation for the academic role. ${ }^{11} \mathrm{Mid}$-career faculty even faces additional teaching and other responsibilities such as grant applications and administrative work load. Recent international studies of occupational therapy (OT) faculty indicate that this picture still applies. ${ }^{12-16}$ Furthermore, published studies on OT academics are few compared with other health science education; available studies utilized qualitative methods. ${ }^{17}$ The adaptation process in academia remains underexplored. This study aimed to develop a questionnaire with established content validity. This questionnaire will be tested using occupational therapy faculty to describe their adaptation process as educators.

\section{Instrument Development}

Instruments in educational research and evaluation must have adequate psychometric properties particularly validity and reliability. ${ }^{18}$ Validity of an instrument ensures that accurate and useful inferences can be drawn from the data. ${ }^{18-19}$
There are three commonly used forms to assess validity: content; concurrent; and construct. ${ }^{18}$ Content validity refers to the extent or degree that items measure the concept or latent attribute that it intends to measure. ${ }^{19-20}$ One way to determine this is by calculating for the item-content validity index (I-CVI) from experts' ratings of item relevance. ${ }^{21}$ Concurrent validity refers to correlation or agreement of results when compared with results from similar tests. ${ }^{18}$ This is obtained by computing for the correlation coefficient of data obtained from two different tests. ${ }^{18}$ It establishes a tool's construct validity. Construct validity is defined as the degree to which items measure hypothetical constructs or concepts. ${ }^{19}$ It is viewed as a "unifying form of validity", encompassing both content and criterion validity. ${ }^{22}$ Construct validity has become the "overriding objective in validity" in recent studies. ${ }^{19}$ Portney and Watkins ${ }^{23}$ opined that a part of construct validity is derived from content validity.

\section{Study purpose}

This paper aimed to address the following research objectives:

1. To develop a questionnaire that will describe the adaptation process of Filipino occupational therapy (OT) educators;

2. To determine the content validity of the questionnaire.

\section{METHOD}

\section{Design}

This study used an instrument development design to develop and determine the content validity of the APA-Q.

\section{Material/Instrument development}

The development of the questionnaire followed the Portney and Watkins ${ }^{23}$ five-step process on instrument development: (1) define the purpose of the instrument; (2) draft an outline of the needed information; (3) review of literature and available instruments to determine its applicability and if these tools can be modified for the study; (4) write and assemble the items; and (5) ask experts to review item relevance and to validate the content.

\section{Definition and purpose of the instrument, and draft outline of the needed information}

The purpose of the instrument was to develop a comprehensive tool to describe the adaptation process of educators. This included describing the challenges, institutional services, policy and support, issues of concern and importance, context factors, adapting responses, and adaptation outcomes of educators.

\section{Review of available instruments}

We conducted a scoping review ${ }^{17}$ of literature to examine the array of research and available instruments relevant to the purpose of the instrument. 


\section{Write and assemble the items}

Using our outline as reference, we selected items that matched our purpose from available surveys and included other items available from literature.

\section{Validation of the content}

We developed an item relevance scale with an openended question for the items that were generated. We set the criteria for selection of experts and identified possible experts.

\section{Participants}

Six experts were recruited to evaluate the relevance of the questions and the answer options. They consisted of faculty from occupational therapy, physical therapy, and speech pathology. The experts were selected based on the following criteria: (1) holder of a master's or doctoral degree; (2) five or more years of academic faculty experience; (3) management experience (e.g., chairperson or member of a regulatory board/ authority). Experts were recruited from the first author's professional network. Content experts in the Philippine allied health context differ from that of developed countries such as the United States. The standard $\mathrm{PhD}$ degree to enter the academe does not apply in the Philippines, considering that $\mathrm{PhD}$ degree holders among OT, PT, and SP are scarce. Furthermore, five years of academic experience is considered expert-level in the Philippine OT academic context.

This study has been registered with the first author's university Research Grants Administration Office (RGAO) and approved by the Research Ethics Board (REB). The approved REB protocol included the instrument development and validation phase.

\section{Data Collection Procedures}

We completed a scoping review to map, summarize, and describe the literature on the topic. ${ }^{17}$

We asked the content experts to rate each item to determine the content validity of the APA-Q. Experts rated each item and/or answer option using an online item relevance scale (not relevant, somewhat relevant, quite relevant, highly relevant ${ }^{21}$ and through an openended question, they wrote their comments on items that were vague, redundant, and that required revisions and suggested additional items that they judged to be relevant for the purpose of the study. The content experts reviewed all of the beta-version of the APA-Q which has a total of 199 items. Participants provided consent to participate by accomplishing and submitting the online survey.

\section{Data analysis}

Content validity was determined by calculating for the item and scale content validity indexes (I-CVI/S-CVI) from experts' ratings. ${ }^{21}$ The I-CVI is the proportion of agreement of experts on item relevance. This is computed by dividing the number of experts giving a rating of 'quite relevant' or 'highly relevant' over the total number of experts. ${ }^{21}$
The I-CVI should be .78 or higher, with six experts. ${ }^{21,24}$ I-CVI lower than .78 were deleted or revised.

The S-CVI is the average of the I-CVIs of all items on the scale. Polit and Beck ${ }^{21}$ recommends a S-CVI of .90 or more for a scale to have excellent content validity. Data were computed using Microsoft Excel for Windows (version 2016).

Qualitative comments were summarized. The I-CVI and qualitative comments were used to delete, revise, substitute, and add items in the developed APA-Q instrument.

\section{RESULTS}

\section{Development of the APA-Q}

Our tool's purpose was to describe the adaptation process of Filipino OT educators in academia. We reviewed literature from four databases and analyzed twenty-eight (28) articles. $^{17}$ Two (2) studies ${ }^{25-26}$ that described faculty survey instruments were found to be similar and could be adapted for our study.

Majority of the instruments and interview protocols used in faculty surveys from literature were researcher-developed to fit the research questions, target study population, and context. For example, Sutherland and Petersen ${ }^{27}$ and Sutherland, Wilson, and Williams ${ }^{25}$ used a semi-structured interview schedule and a survey questionnaire to describe early career academic experience, productivity, and opinions among successful early career academics in New Zealand universities. Their 32 interview questions addressed teaching, research, support, and external factors that have influenced success. They also used an online questionnaire using a four-point Likert scale for most of the items (strongly agree to strongly disagree or very effective-very ineffective or very important-very unimportant).

The online questionnaire addressed items such as demographics, job information, qualifications, home situation, research and teaching activities, institutional policies/support/services, working relationships, worklife balance, and questions related to plan to stay in the institution. Sutherland and colleagues ${ }^{25}$ grouped subscale items based on findings from a principal component analysis. They also assessed the reliability of the scales where alpha scores above 0.7 were accepted.

Kaufman's ${ }^{26}$ 49-item questionnaire used with American physical therapy faculty, addressed socio-demographic profile, environmental, career, work factors, and research productivity. Kaufman ${ }^{26}$ pilot tested $(\mathrm{n}=17)$ the instrument for test-retest consistency, and face and content validity. Each item was assessed for percentage of agreement. Items with less than $75 \%$ agreement were edited for clarity and precision. Written comments affirmed face and content validity that resulted to minor revisions in language. ${ }^{26}$

Sutherland et al.'s $\mathrm{s}^{25}$ and Kaufman's ${ }^{26}$ instruments were modeled from national (e.g., Higher Education Research Institute) and international surveys (e.g., Collaborative on 
Academic Careers in Higher Education, 2010; 2004 Survey on the UK academic workforce). Further examination of the two surveys revealed that items in Sutherland et al.' $\mathrm{s}^{25}$ questionnaire were more appropriate for our information needs.

Based on the scoping review ${ }^{17}$ and using adaptation as theoretical lens, we drafted our outline illustrated in Figure 1. Latent variables are variables or constructs that cannot be directly observed or measured. ${ }^{28}$ For this study, these were adaptation, academic experiences, context factors, adapting responses, and adaptation outcomes. Observable or manifest variables referred to in this study as observable indicators were used to measure the latent variables or constructs. ${ }^{28}$ These observable indicators (e.g., challenges, institutional service, policy, and working relationships or supports) were items in the APA-Q.

The APA-Q was composed of four sections with a total of 199 items each with Likert type scales. The majority of the questions and items were modeled on the instrument by Sutherland et al. ${ }^{25}$ (2013) (adapted with permission; January 12, 2018 personal communication from $\mathrm{K}$ Sutherland to first author). Item groupings or clusters of Sutherland et al. $\mathrm{s}^{25}$ questionnaire were adopted as these were based on results of principal component analyses. It was estimated that the entire survey will take 30-40 minutes to complete based on informal pre-testing of the tool on three faculty colleagues of the first author. The four sections are described below and in Table 1.

\section{Academic experiences}

Majority of the items on academic experiences (except for challenges) were modeled from Sutherland et al.'s ${ }^{25}$ (2013) faculty survey. These were institutional service/ policy, working relationships/supports, issues of concern and importance. Items for the challenges were written based on several key studies summarized into themes published in a scoping review. ${ }^{17}$

\section{Contexts}

Context factors were extracted from social, cultural, political, and economic issues of the country (e.g., migration, globalization) identified by Lorenzo et al. ${ }^{29}$

\section{Adapting responses}

Items in this section were based on several key studies, also described in the scoping review. ${ }^{17}$

\section{Adaptation outcomes}

Items on productivity, confidence, promotion, assessment of professional development, work-life balance, and satisfaction were based on Sutherland et al.'s ${ }^{25}$ (2013) faculty survey.

\section{Profile of Content Experts}

Six experts completed the review of the APA-Q. The median age of the experts is 38.5 years $(\mathrm{IQR}=31-41)$. Both sexes were equally represented. The experts were educators
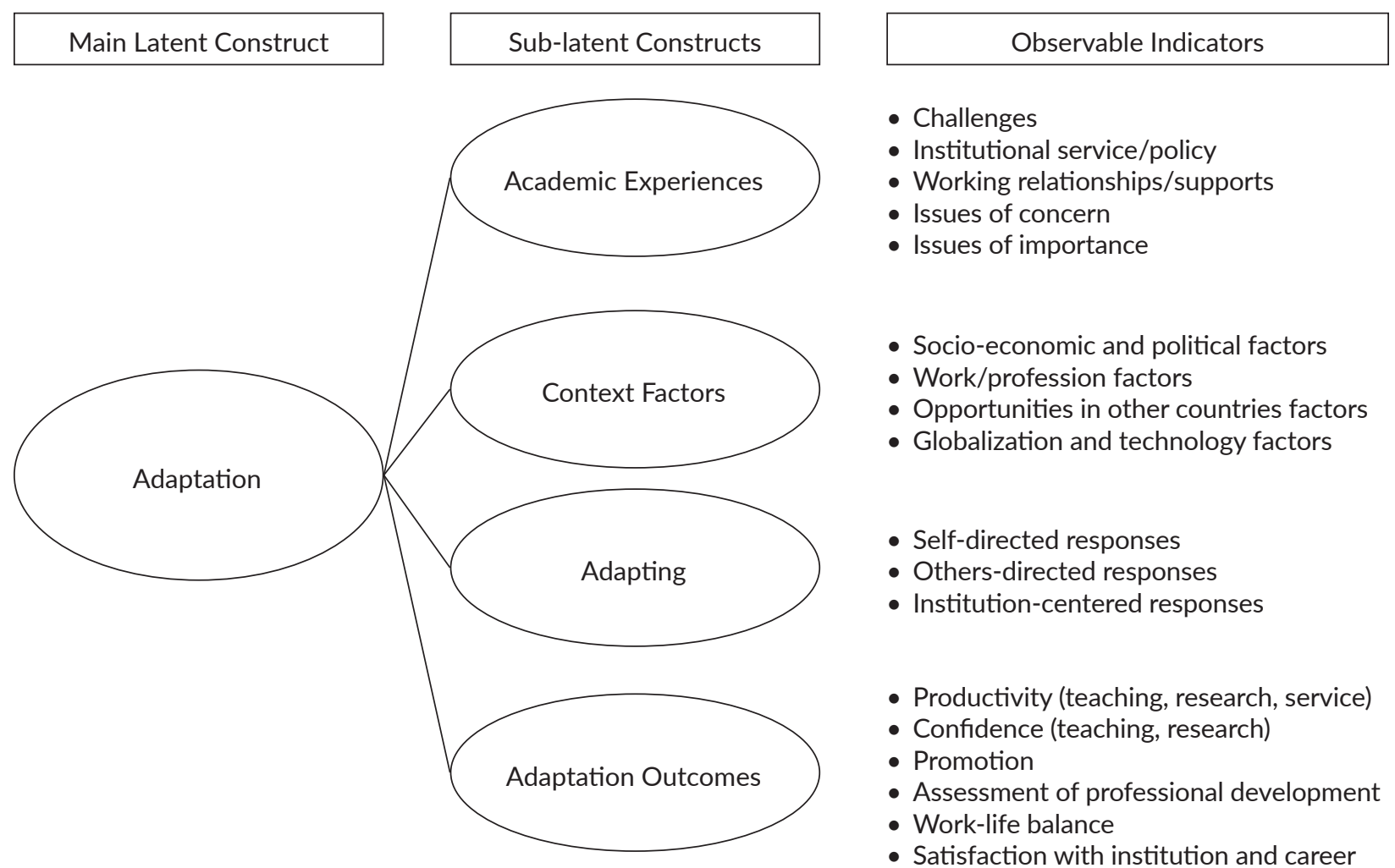

- Challenges

- Institutional service/policy

- Working relationships/supports

- Issues of concern

- Issues of importance

- Socio-economic and political factors

- Work/profession factors

- Opportunities in other countries factors

- Globalization and technology factors

- Self-directed responses

- Others-directed responses

- Institution-centered responses

- Productivity (teaching, research, service)

- Confidence (teaching, research)

- Promotion

- Assessment of professional development

- Work-life balance

- Satisfaction with institution and career

Figure 1. Constructs, sub-constructs, and indicators. 
Table 1. Scale description

\begin{tabular}{|c|c|c|c|c|}
\hline Sub-latent Constructs & Scales and Definitions & $\begin{array}{l}\text { No. of } \\
\text { Items }\end{array}$ & Sample items & Likert scale \\
\hline \multirow{5}{*}{$\begin{array}{l}\text { Academic } \\
\text { experiences }\end{array}$} & $\begin{array}{l}\text { Challenges (situations } \\
\text { or conditions within the } \\
\text { academic environment that } \\
\text { affect fulfillment of role } \\
\text { expectations and demands) }\end{array}$ & 28 & $\begin{array}{l}\text { I have experienced stress balancing } \\
\text { expectations of teaching, research, } \\
\text { service, and other responsibilities }\end{array}$ & $\begin{array}{l}\text { Five-point, } \\
\text { strongly agree - strongly disagree }\end{array}$ \\
\hline & $\begin{array}{l}\text { Institutional service/ } \\
\text { policy (resources that may/ } \\
\text { may not help develop } \\
\text { a faculty's career) }\end{array}$ & 20 & $\begin{array}{l}\text { These services/policies are effective to me: } \\
\text { Formal mentoring program } \\
\text { Assistance in obtaining research grants }\end{array}$ & $\begin{array}{l}\text { Five-point, } \\
\text { Very effective - very ineffective }\end{array}$ \\
\hline & $\begin{array}{l}\text { Working relationships/ } \\
\text { supports (relationship/ } \\
\text { organizational dynamics } \\
\text { within the institution } \\
\text { that may/may not help } \\
\text { develop a faculty's career) }\end{array}$ & 16 & $\begin{array}{l}\text { These working relationships/supports are } \\
\text { effective to me: } \\
\text { Opportunities to participate in decision- } \\
\text { making } \\
\text { Support from department colleagues }\end{array}$ & $\begin{array}{l}\text { Five-point, } \\
\text { Very effective - very ineffective }\end{array}$ \\
\hline & $\begin{array}{l}\text { Issues of concern (academic } \\
\text { issues of personal concern) }\end{array}$ & 19 & $\begin{array}{l}\text { These issues are of concern to me: } \\
\text { Too much focus on teaching rather } \\
\text { than research }\end{array}$ & $\begin{array}{l}\text { Five-point } \\
\text { Very concerning - not concerning } \\
\text { at all }\end{array}$ \\
\hline & $\begin{array}{l}\text { Issues of importance } \\
\text { (academic issues of } \\
\text { personal importance) }\end{array}$ & 21 & $\begin{array}{l}\text { Rate the importance (to you) at the } \\
\text { current time: } \\
\text { Autonomy in my job }\end{array}$ & $\begin{array}{l}\text { Five-point, } \\
\text { Very important - not at all } \\
\text { important }\end{array}$ \\
\hline Context Factors & $\begin{array}{l}\text { Factors affecting } \\
\text { professional academic } \\
\text { career (external } \\
\text { socio-political-economic } \\
\text { factors that may influence } \\
\text { adaptation in the academe) }\end{array}$ & 16 & $\begin{array}{l}\text { The following factors are affecting my } \\
\text { professional academic career: } \\
\text { Low salary }\end{array}$ & $\begin{array}{l}\text { Five-point } \\
\text { Strongly agree - strongly disagree }\end{array}$ \\
\hline Adapting & $\begin{array}{l}\text { Adapting responses } \\
\text { (behavior sets or activities } \\
\text { engaged in that reflect } \\
\text { desire to adapt to } \\
\text { challenging situations) } \\
\end{array}$ & 13 & $\begin{array}{l}\text { To manage my academic work, I seek } \\
\text { resources from the institution }\end{array}$ & $\begin{array}{l}\text { Five-point } \\
\text { Always - never }\end{array}$ \\
\hline \multirow{6}{*}{$\begin{array}{l}\text { Adaptation } \\
\text { outcomes } \\
\text { (mastering } \\
\text { academic roles } \\
\text { and responding to } \\
\text { challenges of the } \\
\text { expected roles and } \\
\text { demands of the } \\
\text { academic work } \\
\text { environment) }\end{array}$} & $\begin{array}{l}\text { Productivity (teaching, } \\
\text { research, service) }\end{array}$ & 27 & $\begin{array}{l}\text { Revised or developed new curriculum } \\
\text { Published articles in peer-reviewed journals } \\
\text { I have received an internal university } \\
\text { service award }\end{array}$ & $0-5$ or more \\
\hline & $\begin{array}{l}\text { Confidence (teaching, } \\
\text { research) }\end{array}$ & 2 & $\begin{array}{l}\text { How confident are you with your research } \\
\text { skills to fulfill your academic role? }\end{array}$ & $\begin{array}{l}\text { Four-point } \\
\text { Very confident - not at all confident }\end{array}$ \\
\hline & Promotion & 1 & $\begin{array}{l}\text { Specify the number of times you have been } \\
\text { promoted during your academic career }\end{array}$ & $\begin{array}{l}\text { Never, Once, Twice, Three times, } \\
\text { Four or more times }\end{array}$ \\
\hline & $\begin{array}{l}\text { Assessment of professional } \\
\text { development }\end{array}$ & 7 & $\begin{array}{l}\text { I am able to meet expectations appropriate } \\
\text { to my faculty rank }\end{array}$ & $\begin{array}{l}\text { Five point } \\
\text { Strongly agree - strongly disagree }\end{array}$ \\
\hline & Work-life balance & 16 & $\begin{array}{l}\text { I am happy with the amount of time } \\
\text { I spend with my family }\end{array}$ & $\begin{array}{l}\text { Five point } \\
\text { Strongly agree - strongly disagree }\end{array}$ \\
\hline & $\begin{array}{l}\text { Satisfaction with } \\
\text { institution and career }\end{array}$ & 13 & I am treated fairly by my employer & $\begin{array}{l}\text { Five-point } \\
\text { Very satisfied - very dissatisfied }\end{array}$ \\
\hline
\end{tabular}

from the fields of occupational therapy $(n=3)$, physical therapy $(n=2)$, and speech and language pathology $(n=1)$. All experts have master's degrees. Three experts have more than five years of academic experience while three have been in the academe for 10 or more years and have the rank of clinical associate professor $(n=1)$ and assistant professor $(n=5)$. Five had held chair positions of their respective departments. One is a member of a government regulatory board and was head of the education program of an international professional association.

\section{Scale-Content Validity Index (S-CVI) and Item- Content Validity Index (I-CVI)}

Content experts were in agreement that over-all, the APA-Q was valid for assessing adaptation process of OT educators (S-CVI = .97) (Table 2). However, they were not in agreement about the relevance of satisfaction, one indicator of adaptation outcome ( $\mathrm{S}-\mathrm{CVI}=0.84$ ).

Content experts agreed that 161 items (81\%) were relevant ( $\mathrm{I}-\mathrm{CVI}=1.0)$, indicating excellent content validity. They also agreed that thirty items (15\%) were acceptable $(\mathrm{I}-\mathrm{CVI}=0.83)$. Content experts rated eight items $(4 \%)$ as 
Table 2. Quantitative and Qualitative Results and List of Deleted, Revised, and Added Items

\begin{tabular}{|c|c|c|c|c|c|c|}
\hline \multicolumn{3}{|c|}{ Quantitative } & \multirow[b]{2}{*}{ Qualitative } & \multicolumn{3}{|c|}{ Questionnaire Items } \\
\hline $\begin{array}{l}\text { Sub-latent } \\
\text { constructs }\end{array}$ & $\begin{array}{l}\text { CVI } \\
\text { Ave }\end{array}$ & $\begin{array}{l}\text { I-CVI Score } \\
\text { Range }\end{array}$ & & Deleted $(n=12)$ & Revised ( $n=13$ ) & Added $(n=10)$ \\
\hline $\begin{array}{c}\text { Academic } \\
\text { Experiences } \\
\quad(n=104)\end{array}$ & 0.96 & $0.5-1.0$ & $\begin{array}{l}\text { 1. Items that lack clarity } \\
\text { - Doubting my competence } \\
\text { as faculty } \\
\text { - Feeling vulnerable as faculty } \\
\text { - Too much administration } \\
\text { - Emotional stress } \\
\text { - Changing modes of delivery } \\
\text { 2. Redundant items } \\
\text { - Struggling in my various } \\
\text { roles as faculty (teacher, } \\
\text { researcher, service provider) } \\
\text { overlapped with stress } \\
\text { balancing expectations of } \\
\text { teaching, research and service } \\
\text { - Better economic, social, } \\
\text { and career opportunities in } \\
\text { other countries overlapped } \\
\text { with Attractive employment } \\
\text { packages in other countries } \\
\text { and Better living conditions } \\
\text { in ther countries }\end{array}$ & $\begin{array}{l}\text { - Struggling in my } \\
\text { various roles } \\
\text { as faculty } \\
\text { - Fear that my } \\
\text { academic career } \\
\text { has plateaued } \\
\text { - Availability and } \\
\text { accessibility of } \\
\text { child care } \\
\text { - Intellectual property } \\
\text { - Influencing } \\
\text { postgraduate } \\
\text { students' } \\
\text { opportunities }\end{array}$ & $\begin{array}{l}\text { - Doubting my } \\
\text { competence } \\
\text { as faculty } \\
\text { - Feeling } \\
\text { vulnerable } \\
\text { as faculty } \\
\text { - Emotional stress } \\
\text { - Need to manage } \\
\text { my time more } \\
\text { efficiently } \\
\text { - Challenges to } \\
\text { meet tenure } \\
\text { requirements } \\
\text { - Too much focus } \\
\text { on quality } \\
\text { assurance } \\
\text { - Too much } \\
\text { administration } \\
\text { - Changing modes } \\
\text { of delivery }\end{array}$ & $\begin{array}{l}\text { - Attending to } \\
\text { students' needs } \\
\text { - Designing effective } \\
\text { or good quality } \\
\text { lectures, exams, } \\
\text { and other teaching- } \\
\text { learning activities } \\
\text { - Fulfilling service, } \\
\text { community or } \\
\text { professional } \\
\text { obligations } \\
\text { - Working on } \\
\text { or developing } \\
\text { relationships with } \\
\text { others (external } \\
\text { collaborators, } \\
\text { community partners) } \\
\text { - Difficulty } \\
\text { developing a niche } \\
\text { or area of expertise/ } \\
\text { specialization } \\
\end{array}$ \\
\hline $\begin{array}{l}\text { Context } \\
\text { Factors } \\
(n=16)\end{array}$ & 0.94 & $0.83-1.0$ & $\begin{array}{l}\text { - Stress on how to advance my } \\
\text { academic career overlapped } \\
\text { with fear that my academic } \\
\text { career has plateaued. } \\
\text { 3. Use of jargon and } \\
\text { suggestion to use additional }\end{array}$ & $\begin{array}{l}\text { - Attractive } \\
\text { employment } \\
\text { packages in other } \\
\text { countries } \\
\text { - Better living } \\
\text { conditions in } \\
\text { other countries }\end{array}$ & $\begin{array}{l}\text { Better } \\
\text { economic, social, } \\
\text { and career } \\
\text { opportunities in } \\
\text { other countries }\end{array}$ & None \\
\hline $\begin{array}{c}\text { Adapting } \\
\text { Responses } \\
(n=13)\end{array}$ & 0.96 & $0.66-1.0$ & $\begin{array}{l}\text { - Quality assurance - } \\
\text { use accreditation } \\
\text { 4enure - use permanent status } \\
\text { 4. Missing items. Items that } \\
\text { were omitted and deemed } \\
\text { important to add }\end{array}$ & None & $\begin{array}{l}\text { - I reflect on my } \\
\text { experiences } \\
\text { - Do things } \\
\text { differently } \\
\text { - Manage my time } \\
\text { - Attend faculty } \\
\text { dev programs } \\
\end{array}$ & None \\
\hline $\begin{array}{l}\text { Adaptation } \\
\text { Outcomes } \\
\quad(n=66)\end{array}$ & 0.96 & $0.66-1.0$ & $\begin{array}{l}\text { - Difficulty choosing/developing } \\
\text { a niche/area of expertise } \\
\text { - Building relationships with } \\
\text { other individuals such as } \\
\text { external collaborations and } \\
\text { with community partners) } \\
\text { - Stress in designing good quality } \\
\text { lectures, exams and other } \\
\text { teaching-learning activities } \\
\text { 5. Others. Additional qualifiers to } \\
\text { instructions to help respondents } \\
\text { frame their responses. Example } \\
\text { cited was ... "effective in managing } \\
\text { or building one's career." }\end{array}$ & $\begin{array}{l}\text { - I plan to remain at } \\
\text { my institution for } \\
\text { the rest of my career } \\
\text { - People comment } \\
\text { on my high number } \\
\text { of work hours } \\
\text { - I feel strong loyalty } \\
\text { to my discipline } \\
\text { - I am proud to } \\
\text { be a member of } \\
\text { this profession } \\
\text { - I would turn down a } \\
\text { higher salary to stay } \\
\text { in this profession }\end{array}$ & None & $\begin{array}{l}\text { - Designed exams or } \\
\text { assessment schemes } \\
\text { - Coordinated } \\
\text { course teams } \\
\text { - Advised/ mentored } \\
\text { students (academic) } \\
\text { - Advised/mentored } \\
\text { students (research } \\
\text { projects) } \\
\text { - Reviewed research } \\
\text { proposals/ } \\
\text { manuscripts }\end{array}$ \\
\hline
\end{tabular}

$\mathrm{CVI}=$ content validity index; $\mathrm{I}-\mathrm{CVI}=$ item $\mathrm{CVI}$

not relevant $(\mathrm{I}-\mathrm{CVI}=0.5-0.66)$ indicating low content validity (Table 2). The proportion of agreement among the six experts on item relevance for each sub-latent construct ranged from 92 to 100 percent: academic experiences (95\%), context factors (100\%), adapting responses (92\%) and adaptation outcomes (95\%).

\section{Qualitative assessment}

Qualitative feedback from content experts can be summarized into the following: items that lack clarity, items that are redundant, use of jargon, need for qualifiers in the instructions, and missing items (Table 2). 


\section{Items that lack clarity}

Experts identified items that were vague and need to be clarified and revised for precision. Examples of these items were "feeling vulnerable as faculty" and "too much administration." According to one expert, feeling vulnerable could mean different things for faculty. For example, it could mean exposure to "criticism and correction" or being susceptible to "threats from students, peers, and parents." The item, "too much administration" is not clear if it only refers to faculty who hold administrative positions or if it also represents faculty who manage course teams and work with college committees.

\section{Redundant items}

These referred to items that can be integrated, combined, or merged with other items. Experts cited items that were similar to others and suggested either making these distinct or combining them. For example, the items, "struggling in my various roles as faculty (teacher, researcher, service provider)" and "stress balancing expectations of teaching, research, service and other responsibilities" were viewed to be the same.

\section{Use of jargon}

This referred to some terms that were viewed to be unfamiliar to the target population. These terms include quality assurance and tenure. It was one expert's view that these terms may not be commonly used by academics in many parts of the Philippines, especially for those whose responsibilities are primarily teaching. Young faculty, who one expert viewed as the majority of allied health faculty in the Philippines may also not be familiar with the term tenure. Additional descriptions were suggested to these two terms. For example, use accreditation as an example of quality assurance. Permanent job position was suggested to be added to tenure. These examples were judged to be more familiar and hence, more understood by the target respondents.

\section{Additional qualifiers to instructions}

Additional descriptions were suggested in the instructions for the categories of service/policy, working relationships/supports, key issues of concern and importance. For example, add the phrase, "...effective in terms of managing daily academic work or building one's academic career". Adding these descriptions or qualifiers will help participants frame their responses.

\section{Missing items}

Additional items were suggested for the following sections: challenges, teaching productivity, research productivity (Table 2). Two experts also suggested adding items to reflect service or community engagement.

In summary, as a result of I-CVI ratings and qualitative feedback and by consensus, we deleted 12 items and revised 13 items. We added ten items (five to challenges and five to productivity) (Table 2).

\section{DISCUSSION}

This study focused on developing and determining the content validity of the APA-Q. The APA-Q was developed to describe faculty adaptation process in the academic setting.

There are a wide variety of faculty surveys (e.g., American Occupational Therapy Association [AOTA] Faculty Survey). These surveys are tailored according to purpose, intended use, target population, and higher education contexts. Information commonly asked in faculty surveys are rank, educational qualifications, length of service, teaching experiences, and performance evaluation. ${ }^{26}$ The unique features of the APA-Q were the items on challenges, context factors, and adapting responses. Challenges encountered in the academe and how faculty responded to these have been described using qualitative studies. ${ }^{12-13,15-17}$ Findings of these qualitative studies were helpful in generating and grouping items for challenges and adapting responses. Indicators for adaptation outcomes (e.g., productivity, promotion) are usually described in other tools as performance metrics. ${ }^{26}$ In the APA-Q, these indicators were viewed as outcomes of adaptation.

A seeming strength of this tool is that it is theory-based. Indicators (e.g., challenges, adapting responses) were drawn from a scoping review ${ }^{17}$ that used theories of adaptation as its analytical framework. Adaptation emerges and evolves when the academic transacts with the academic environment described in this tool as academic experiences. Adaptation theory also includes factors in the environment (context) that may or may not affect adaptation in the academe. Adapting responses and adaptation outcomes reflect a person's capacity to respond adaptively to academic experiences. ${ }^{4-5}$

Content is vital in instrument development and this refers to themes, wording, and item or question format. ${ }^{30}$ One evidence to validity of content is having a panel of experts assess the relevance and clarity of items. ${ }^{30}$

Findings showed that S-CVI was excellent, with majority of items with acceptable I-CVI. Content experts generally agreed on relevance for majority of the items. Quantitative CVI ratings and qualitative feedback were used to inform revisions of the questionnaire.

The S-CVI/average of the latent sub-constructs of academic experiences, contexts, adapting responses and adaptation outcomes is high. The high S-CVI ratings of majority of the subscales can be attributed to the fact except for challenges and adapting responses, these items were subjected to principal component analysis and reliability testing in the Sutherland et al. ${ }^{25}$ study. In the Sutherland et al ${ }^{25}$ study, items below 0.7 were deleted. Moreover, these scales were used among early career academics in New Zealand and the content experts of this study may be considered early career academics based on their years of experience and ages. ${ }^{25}$

The subscale on satisfaction had the lowest S-CVI. Qualitative assessment of one expert found this subscale as 
generally irrelevant to the purpose of the study. This subscale was retained although three items were deleted. Our decision to retain satisfaction was drawn from the assertions of Grajo ${ }^{6}$ and Savickas ${ }^{4}$ that satisfaction is one indicator of adaptation.

We also chose to revise instead of delete two items that had low I-CVI. These items are "too much administration" and "do things differently." The decision to revise the first item was based on qualitative feedback that it could refer to administrative workload for those in administrative positions or it could also mean managing a course or attending meetings. We viewed these comments as contextually relevant to OT educators. The latter item was revised because it lacked clarity and needed more information. In this case, we cited specific examples such as organizing work and following a schedule.

We deleted items with acceptable I-CVI such as influencing post-graduate students' opportunities in consideration that almost all OT schools (except for two) only offer bachelor's degrees. Other items with similar I-CVI were deleted as they were regarded to be redundant.

One important aspect of content validation is identifying areas or items that were omitted. ${ }^{24}$ For this study, five items were suggested as additional challenges deemed relevant to local academic practices. These included attending to students' needs (academic and non-academic issues), designing good quality lectures and examinations, fulfilling service or community obligations, developing relationships or networks with others, and developing a niche or area of specialization. These suggested items that reflected the experts' immersion in the academe represented their expertise, different from the standard of expert in academic institutions in developed economies and established disciplines.

Clear instructions are essential in instrument development. There were scales that needed additional qualifiers to enable respondents to frame their responses. For example, one scale asked to rate effectivity of institutional service or policy. One expert suggested adding "effective in terms of building/managing their academic career."

The limitation of the study was that it did not include qualitative assessment of the items from the target population. The APA-Q is currently undergoing testing for construct validity and reliability with a sample from the Filipino OT educator population.

\section{CONCLUSION}

Results indicated that the APA-Q is a descriptive tool with items that are deemed relevant by content experts. It is a promising tool to describe educators' adaptation process. The APA-Q has good potential for use with quantitative or mixed methods studies.

\section{Acknowledgment}

We express our gratitude to the content experts who shared their time and expertise.

\section{Statement of Authorship}

All authors contributed to the conceptualization of the study, data analysis, and writing of the manuscripts. All authors approved the final manuscript.

\section{Author Disclosure}

All authors declared no conflicts of interest.

\section{Funding Source}

The first author is supported by a Local Doctoral Fellowship Program under the Faculty, REPS and Administrative Staff Development Program of the University of the Philippines System.

\section{REFERENCES}

1. World Federation of Occupational Therapists, Definition of occupation [Internet]. 2012 [cited 2019 Aug]. Available from https://www.wfot.org/about-occupational-therapy

2. Grajo LC, Boiselle AK, Dalomba E. Defining the construct of occupational adaptation. In: Grajo LC, Boiselle AK, eds. Adaptation through Occupation: Multidimensional Perspectives, Thorofare, NJ, USA: Slack Incorporated; 2019. pp.3-18.

3. Schkade JK, Schultz S. Occupational adaptation: Toward a holistic approach for contemporary practice, part I. Am J Occup Ther. 1992; 46(9):829-37.

4. Savickas M. Career construction theory and practice. In: Brown SD, Lent W, eds. Career development and counseling: Putting theory and research to work, 2nd ed. Hoboken, NJ: Wiley; 2013. pp. 42-70.

5. Schkade J, Schultz S. Occupational adaptation. In: Kramer P, Hinojosa J, Royeen CB, eds. Perspectives in human occupationParticipation in life, Philadelphia: Lippincott Williams \& Wilkins; 2003. pp.181-221.

6. Grajo L. Occupational adaptation. In: Hinojosa J, Kramer P, Royeen $\mathrm{CB}$, eds. Perspectives on Human Occupation-Theories underlying Practice, 2nd ed. Philadelphia: F.A. Davis; 2017. pp. 287-311.

7. Savickas ML, Porfeli EJ. Career adapt-abilities scale: Construction, reliability, and measurement equivalence across 13 countries. J Vocat Behav. 2012; 80(3):661-73.

8. Kezar A, Maxey D. Faculty Matter: So why doesn't everyone think so. The NEA High Educ J Thought \& Action [Internet]. Fall 2014 [cited 2019 Aug]; 29-44. Available from https://www.nea.org/assets/ docs/HE/e-Kezar.pdf

9. World Health Organization Guidelines. Transforming and scaling up health professionals' education and training. Geneva, Switzerland: WHO; 2013.

10. Sana EA. Evaluation of teachers in the health professions. In: Sana EA, ed. Teaching and learning in the health professions. Quezon City, Philippines: The University of the Philippines Press; 2010. pp. 312-333.

11. Kahanov L, Eberman L, Yoder A, Kahanov M. Culture shock: Transitioning from clinical practice to educator. Internet J Allied Health Sci Pract [Internet]. 2012 Jan [cited 2019 Aug];10(1). Available from https://nsuworks.nova.edu/ijahsp/vol10/iss1/7/

12. Carra KA, Fortune T, Ennals P, D'Cruz K, Kohn H. Supporting scholarly identity and practice: Narratives of occupational therapy academics. Br J Occup Ther. 2017;80(8):502-9.

13. Ennals P, Fortune T, Williams A, D'Cruz K. Shifting occupational identity: Doing, being, becoming and belonging in the academy. High Educ Res Dev [Internet]. 2015 Nov 18 [cited 2019 August];35(3). Available from http://dx.doi.org/10.1080/07294360.2015.1107884

14. Foy C. Identifying barriers and pathways to success for new occupational therapy faculty members: A pilot survey. Occup Ther Health Care [Internet]. 2017 Aug 24 [cited 2019 Aug]; 31(4). Available from https://doi.org/10.1080/07380577.2017.1354269 
15. Murray C, Stanley M, Wright S. Weighing up the commitment: A grounded theory of the transition from occupational therapy clinician to academic. Aust Occup Ther J. 2014; 61(6):437-45.

16. Fortune T, Ennals P, Bhopti A, Nielson C, Darzins S, Bruce C. Bridging identity 'chasms': occupational therapy academics' reflections on the journey towards scholarship. Teach High Educ [Internet]. 2016 [cited 2019 Aug]; Available from http://doi.org/ 10.1080/13562517.2016.1141289

17. Cabatan MC, Grajo L, Sana EA. A scoping review of challenges and the adaptation process in academia: Implications for occupational therapy educators. Open J Occup Ther [Internet]. 2019 [cited 2019 Aug];7(1): Article 8; Available from https://doi.org/10.15453/21686408.1523

18. Sana EA. Evaluation in health science education. In: Sana EA, ed. Teaching and learning in the health professions. Quezon City, Philippines: The University of the Philippines Press; 2010. pp. 182-202.

19. Creswell JW. Research design: Qualitative, Quantitative, \& Mixed Methods Approaches, 4th ed. Thousand Oaks, CA: SAGE; 2014.

20. Cappelleri JC, Lundy JJ, Hays RD. Overview of classical test theory and item response theory for the quantitative assessment of items in developing patient-reported outcome measures. Clin Ther. 2014; 36(5):648-62.

21. Polit DF, Beck CT. The content validity index: Are you sure you know what's being reported? Critique and recommendations. Res Nurs Health. 2006; 29(5):489-97.

22. Strauss ME, Smith GT. Construct validity: Advances in theory and methodology. Annu Rev Clin Psychol. 2009; 5:1-25.
23. Portney L, Watkins M. Foundations of Clinical ResearchApplications to Practice, 3rd ed. Upper Saddle River, NJ: Pearson Education; 2009.

24. Lynn MR. Determination and quantification of content validity. Nurs Res. 1986; 35(6): 382-5.

25. Sutherland K, Wilson M, Williams P. Research report: Success in academia? The experiences of early career academics in New Zealand universities. Wellington, NZ: Ako Aotearoa National Centre for Tertiary Teaching Excellence; 2013.

26. Kaufman RR. Career factors help predict productivity in scholarship among faculty members in physical therapist education programs. Phys Ther. 2009;89(3):204-16.

27. Sutherland K, Petersen L. The success and impact of early career academics in two New Zealand Tertiary institutions. Wellington, NZ: Aotearoa National Centre for Tertiary Teaching Excellence; 2009.

28. DeVellis RF. Scale Development: Theory and Applications, 3rd ed. Thousand Oaks, CA: SAGE; 2012.

29. Lorenzo F, Dela Rosa J, Ronquillo K, Mercado R, Villegas S. Philippines Mobility of Health Professionals. Manila: Institute of Health Policy and Development Studies, National Institutes of Health, University of the Philippines Manila; 2012.

30. American Educational Research Association, American Psychological Association, and National Council on Measurement in Education. Standards for Educational and Psychological Testing, Washington, DC; 2014. 